\title{
Hubungan Paritas Dan Anemia Dengan Kejadian Ketuban Pecah Dini (KPD) Pada Ibu Bersalin Di RSUD Panembahan Senopati Bantul
}

\author{
Relationship Between Parity And Anemia With Premature Rupture Of Membrans (PROM) \\ Incidence On Mother's Delivery In The Regional Public Hospital Of \\ Panembahan Senopati Bantul
}

\author{
Faridha Natsir ${ }^{1}$, Rismayana $^{2}$, Evi Wahyuntari $^{3}$ \\ Akademi Kebidanan Graha Ananda Palu \\ Email : faridhanatsir@gmail.com
}

\begin{abstract}
Abstrak
Ketuban pecah dini atau premature rufture of membran (PROM) pecahnya ketuban sebelum adanya tanda persalinan, pecahnya ketuban sebelum adanya inpartu dengan pembukaan pada primipara kurang dari $3 \mathrm{~cm}$ dan pada multipara kurang dari $5 \mathrm{~cm}$. Penelitian ini bertujuan untuk mengetahui hubungan paritas dan anemia dengan kejadian ketuban pecah dini pada ibu bersalin di RSUD Panembahan Senopati Bantul. Desain penelitian yang digunakan adalah survey analitik dengan pendekatan Retrospektif dengan metode case control, pengumpulan data dimulai dari efek atau akibat yang mungkin terjadi kemudian diketahui penyebabnya atau variabel dan membandingkan kelompok kasus dan control secara yang diambil secara random sampling. Analisis bivariate yaitu chi square. Hasil analisis didapatkan yang mengalami KPD sebanyak 60 orang (60.0\%) sedangkan paritas berisiko 24 orang $(40.0 \%)$, dan anemia berisiko 26 orang $(43.3 \%)$, hubungan kejadian anemia dan paritas dengan ketuban pecah dini, hasil uji statistic chi square dalam penelitian ini di peroleh nilai p-value sebesar 0.011 dan $0.001(p$-value $<0.05)$ OR 2.765 dan 0.286. Sehingga terdapat hubungan yang signifikan antara paritas dan anemia dengan ketuban pecah dini (KPD) di RSUD Panembahan Senopati Bantul. Diharapkan bagi ibu hamil disarankan untuk secara teratur melakukan pemeriksaan ANC selama kehamilan dan meminum tablet tambah darah secara teratur untuk mencegah komplikasi kehamilan akibat dari anemia yang salah satunya adalah ketuban pecah dini, dan disarankan menikah pada usia reproduktif (20-35 tahun).
\end{abstract}

Kata Kunci : Anemia, Ibu Bersalin, KPD, Paritas

\begin{abstract}
Premature rupture of membranes (PROM) is rupture of the membranes before birth signs, rupture of membranes before inpartum with opening in primiparous less than $3 \mathrm{~cm}$ and in multiparous less than $5 \mathrm{~cm}$. The study aims to investigate the relationship between parity with premature rupture of membranes incidence on mother's delivery in the Regional Public Hospital of Panembahan Senopati Bantul. This is analytical survey study with case control approach. Data collection consisted of collecting effects that might occur, finding out causes or variables, and comparing groups of cases and control retrospectively, thus it could be used in finding out risk factors (parity and anemia) on PROM. Bivariate analysis used chi square. The result of statistical test was 60 (60\%) women with PROM, 24 (40\%) women with parity risk, and 26 (43.3\%) women with anemia risk. Besides, the relationship between anemia and parity with PROM was shown by $p=0.011$ and 0.001 ( $p$-value $<0.05$ ), OR 2.765 and 0.286. it is expected that pregnant women will regulary conduct ANC examinations during pregnant and take blood added tablets regularly to prevent pregnancy complications due to anemia, one of which is premature rufture of membranes, it is also recommended to get married at reproductive age (20-35 years).
\end{abstract}

Keywords: Anemia, KPD, Mother's Delivery, Parity 


\section{PENDAHULUAN}

Ketuban pecah dini atau premature rufture of membran (PROM) adalah pecahnya ketuban sebelum adanya tanda persalinan [1], sedangkan menurut Mochtar atau karena pecahnya ketuban sebelum adanya inpartu dengan pembukaan pada primipara kurang dari $3 \mathrm{~cm}$ dan pada multipara kurang dari $5 \mathrm{~cm}$, yang disebabkan oleh karena berkurangnya kekuatan membran atau meningkatnya tekanan intrauterine kedua faktor tersebut [2].

Menurut hasil Survei Demografi dan Kesehatan Indonesia (SDKI) 2012, angka kematian ibu menunjukkan kenaikan dari 228 di tahun 2007 menjadi 359 kematian ibu per 100.000 kelahiran hidup di tahun 2012 [3]. Angka ini masih cukup tinggi jika dibandingkan dengan negara-negara tetangga ASEAN. Berdasarkan data dari kementerian kesehatan RI, kematian ibu di Indonesia masih didominasi oleh tiga penyebab utama kematian yaitu perdarahan (30,3\%), hipertensi dalam kehamilan $(27,1 \%)$ dan infeksi $(7,3 \%)$.

Salah satu penyebab infeksi adalah kejadian ketuban pecah dini yang tidak mendapat penanganan segera. Ketuban pecah dini (KPD) termasuk komplikasi kebidanan selama kehamilan, komplikasi kematian pada ibu dan janin. Cakupan penanganan komplikasi secara nasional pada tahun 2013 ialah 73,31 \% (Kemenkes, 2014). Menurut WHO pada tahun 2012 kejadian ketuban pecah dini (KPD) berkisar 5-10 \% dari semua kelahiran. KPD preterm terjadi 1\% dari semua kehamilan dan $70 \%$ kasus KPD terjadi pada kehamilan aterm. Adapun pada kasus $30 \%$ KPD merupakan penyebab kelahiran premature[4].

Berdasarkan data SDKI (2012) adanya tiga penyebab utama adalah perdarahan, pre-eklamsi dan infeksi. Sedangkan Angka Kematian Ibu (AKI) di Provinsi DIY pada tahun 2011 sebesar 56/100.000 kelahiran hidup, tahun 2012 menurun menjadi 40/100.000 kelahiran hidup namun pada tahun 2013 mengalami kenaikan sebesar 46/100.000 kelahiran hidup [5].

Anemia merupakan masalah gizi yang mempengaruhi jutaan tetap menjadi tantangan besar bagi kesehatan. Anemia ibu dikaitkan dengan morbiditas pada ibu dan bayi, termasuk resiko keguguran, kelahiran mati, prematuritas dan berat badan rendah.

Penyebab utama kematian ibu dan bayi rata-rata disebabkan pendarahan, hipertensi saat kehamilan, pernikahan usia muda infeksi akibat ketuban pecah dini, ketuban pecah dini masih belum diketahui dan tidak dapat ditentukan secara pasti, maka usaha preventif tidak dapat dilakukan kecuali dalam usaha menekan infeksi. Kemungkinan yang menjadi faktor predisposisi adalah infeksi, keadaan sosial ekonomi, overdistensi uterus, serviks inkompeten, kelaina letak janin, paritas, anemia, riwayat ketuban pecah dini pada kehamilan sebelumnya, merokok selama kehamilan, usia ibu dan riwayat hubungan seksual [6].

Berdasarkan studi pendahuluan yang dilakukan di RSUD Panembahan Senopati Bantul, hasil observasi awal pada register persalinan pada bulan Januari sampai November 2017 didapatkan 1901 ibu bersalin , diantaranya 60 responden yang mengalami ketuban pecah dini, dan 60 responden yang tidak mengalami ketuban pecah dini, maka penulis tertarik untuk melakukan penelitian tentang Hubungan paritas dan anemia dengan kejadian ketuban pecah dini (KPD) pada ibu bersalin di RSUD Panembahan Senopati Bantul tahun 2017.

\section{METODE}

Jenis penelitian ini merupakan penelitian kuantitatif dengan desain penelitian yang digunakan adalah survei analitik dengan rancangan studi kasus control pendekatan retrospektif. Populasi dalam penelitian ini adalah hasil studi dokumentasi yang diambil dari rekam medik tentang data ibu bersalin tahun 2017 yang mengalami ketuban pecah dini di RSUD Panembahan Senopati Bantul yaitu sejumlah 60 kasus ibu mengalami KPD dan 60 ibu yang tidak mengalami KPD, dari 1901 seluruh ibu bersalin normal. Sampel dalam penelitian ini mengambil seluruh jumlah yang terdapat pada 
populasi.

\section{HASIL}

Analisis bivariat dalam penelitian ini menggunakan uji chi square untuk menentukan hubungan Paritas dan anemia dengan kejadian ketuban pecah dini pada ibu bersalin di RSUD Panembahan Senopati Bantul 2017 dapat diketahui pada tabel di bawah ini:

Tabel 1. Hubungan Paritas dan Anemia dengan kejadian ketuban pecah dini di RSUD Panembahan Senopati Bantul 2017

\begin{tabular}{|c|c|c|c|c|c|c|}
\hline \multirow{2}{*}{ Variabel } & \multicolumn{2}{|c|}{ KPD berisiko } & \multicolumn{2}{|c|}{ KPD tidak berisiko } & \multirow{2}{*}{ P value } & \multirow{2}{*}{$O R$} \\
\hline & $\mathbf{n}$ & $\%$ & $\mathbf{n}$ & $\%$ & & \\
\hline \multicolumn{5}{|l|}{ Paritas } & \multirow{3}{*}{0.001} & \multirow{3}{*}{0.286} \\
\hline Berisiko & 24 & 40.0 & 42 & 70.0 & & \\
\hline Tidak Berisiko & 36 & 60.0 & 18 & 30.0 & & \\
\hline \multicolumn{5}{|l|}{ Anemia } & \multirow{3}{*}{0.011} & \multirow{3}{*}{2.765} \\
\hline Anemia & 26 & 43.3 & 13 & 21.7 & & \\
\hline Tidak Anemia & 34 & 56.7 & 47 & 78.3 & & \\
\hline
\end{tabular}

Sumber : Data Rekam Medik, 2017

Table 1 menunjukkan bahwa berdasarkan kategori paritas berisiko sebanyak 24 responden (40.0\%) dan tidak berisiko sebanyak 36 responden (60.0\%) tapi berisiko mengalami ketuban pecah dini, sedangkan yang mengalami anemia sebanyak 26 responden (43.3\%), tidak anemia sebanyak 34 responden (56.7\%) dan mengalami ketuban pecah dini. Berdasarkan uji statistic menggunakan Chi Square didapatkan nilai p-value sebesar 0.011 , value $\leq \alpha(\alpha=0,05)$, dan koefisiensi korelasi sebesar 2,765 sehingga dapat disimpulkan Ha diterima Ho ditolak yang berarti terdapat hubungan anemia dengan ketuban pecah dini di RSUD Panembahan Senopati Bantul Tahun 2017.

\section{PEMBAHASAN}

1. Hubungan paritas dengan Kejadian Ketuban pecah dini

Berdasarkan hasil penelitian yang telah dilakukan menunjukkan bahwa ada hubungan antara paritas dengan kejadian KPD, analisis data menggunakan Chi Square didapatkan $p$ value $(0,001)$ lebih kecil dari $\alpha(0,05)$ dan koefisiensi korelasi sebesar 0,286 sehingga dapat disimpulkan yang artinya ada hubungan antara paritas dengan kejadian KPD. Hasil penelitian ini sesuai dengan teori manuaba (2010) yang menyatakan bahwa paritas merupakan faktor penyebab terjadinya ketuban pecah dini, dan menurut Morgan \& Hamilton (2009), paritas merupakan salah satu faktor yang mengakibatkan ketuban pecah dini karena peningkatan paritas yang memungkinkan kerusakan serviks selama proses kelahiran sebelumnya. Hal ini bukan disebabkan aktivitas uterus melainkan kelemahan intrinsik uterus yang disebabkan oleh trauma sebelumnya pada servik khususnya pada tindakan riwayat persalinan pervaginam, dilatasi serviks, kuretase. Selain itu susunan serviks pada multipara lebih banyak serabut saraf daripada jaringan ikat dibanding serviks normal.

Rusaknya jaringan serviks tersebut maka kemungkinan otot dasar dari uterus meregang. Proses peregangan terjadi secara mekanis yang merangsang beberapa faktor di selaput ketuban seperti prostaglandin E2 dan interleukin-8. Hal-hal tersebut akan menyebabkan terganggunya kesimbangan proses sintesis dan degradasi matriks ektraseluler yang akhirnya menyebabkan ketuban pecah. Aktivitas kehamilan multiple, pengaruh hormone dan infeksi dapat berperan sebagian. 
Penelitian menurut Merti demiarti (2016), mengatakan Berdasarkan data ibu bersalin dengan KPD di RSU PKU Muhammadiyah Bantul tahun 2016 sebagian besar memiliki paritas 2-3 (multipara) sebanyak 68 orang $(80,0 \%)$ yang terdiri dari 11 orang $(12,95)$ pada kehamilan preterm dan 57 orang $(67,1 \%)$ pada kehamilan aterm [7]. Penelitian ini sejalan dengan penelitian Sari (2014), yang menyatakan bahwa kejadian KPD di Puskesmas Balongsari Surabaya tahun 2013 lebih banyak terjadi pada paritas multipara (31,17 \%) [8].

Hal ini didukung juga oleh penelitian Rahmawati (2015), yang dilakukan di RSUD Sunan Kalijaga Demak, yang menyebutkan faktor paritas lebih banyak terjadi yaitu kelompok multipara sebanyak 48 \% yang dapat mempengaruhi terjadinya ketuban pecah dini [9]. Menurut Nugroho (2010) penyebab ketuban pecah dini salah satunya multigravida, karena pada multigravida kanalis servikalis selalu terbuka oleh karena melahirkan lebih dari 1 kali. Sedangkan pada kelainan letak menjadi salah satu faktor predisposisi ketuban pecah dini karena pada letak sungsang tidak ada bagian terendah yang menutupi pintu atas panggul (PAP) yang dapat menghalangi tekanan terhadap membran bagian bawah [10].

2. Hubungan Anemia dengan Kejadian Ketuban pecah dini

Berdasarkan hasil penelitian didapatkan bahwa anemia pada ibu bersalin di RSUD Panembahan Senopati Bantul meliputi, ibu yang mengalami anemia sebanyak 39 orang (32.5 \%) dan ibu yang mengalami tidak anemia sebanyak 81 orang (67.5\%). Berdasarkan penelitian yang dilakukan, hasil uji chi square menunjukan nilai p-value sebesar 0.011 nilai hasil uji ini untuk menentukan ada tidaknya hubungan. Maka taraf signifikansi $\alpha$ lebih besar dari $0,05(0,011>0,05)$ maka dapat disimpulkan bahwa Ha diterima dan Ho ditolak berarti ada hubungan antara paritas dengan ketuban pecah dini pada ibu bersalin di RSUD Panembahan Senopati Bantul tahun 2017. Teori dari Manuaba (2010) menyatakan bahwa anemia selama kehamilan menyebabkan ibu hamil tidak begitu mampu menghadapi kehilangan darah dan membuatnya rentan terhadap infeksi. Anemia juga mengakibatkan hipoksia fetal dan persalinan premature yang berbahaya bagi ibu dan janin.

Adanya anemia akan menghambat janin menyerap berbagai nutrisi dari ibunya, serta kemampuan metabolisme tubuh akan berkurang sehingga pertumbuhan dan perkembangan janin dalam rahim akan terganggu. Penyebab kepada ibu secara langsung adalah terjadinya ketuban pecah akibat anemia pada masa kehamilan.

Sesuai dengan teori Manuaba (2007) di atas bahwa komplikasi yang disebabkan anemia pada ibu hamil dapat membahayakan ibu dan bayi, sehingga dapat meningkatkan angka kesakitan dan kematian [11]. Anemia selama kehamilan sebagian besar disebabkan karena kekurangan besi (anemia defisiensi besi) karena unsurnya besi dalam makanan, gangguan reabsorbsi atau karena terlampau banyaknya besi keluar dalam tubuh [12].

Sesuai dengan teori Cunningham (2009) Wanita hamil dengan anemia menyebabkan daya tahan tubuh dan suplai nutrisi ke janin menjadi berkurang. Kadar hemoglobin yang rendah memungkinkan wanita hamil mudah mengalami infeksi. Defisiensi nutrisi dapat mempengaruhi respon tubuh terhadap infeksi dan kekuatan membrane kolagen, abnormalitas struktur kolagen dan perubahan matriks ekstraseluler. Anemia mempengaruhi kekuatan respon tubuh terhadap infeksi dan fungsi imun yang mengakibatkan penurunan kemampuan sel [13].

Mekanisme infeksi akan menganggu proses kolagenolitik sehingga terjadi gangguan keseimbangan antara produksi matrix metalloproteinase (MMP) yaitu enzim yang diproduksi oleh matriks ekstra ekstraseluler termasuk kolagen dan tissue inhibitor of metalloproteinase (TIMP) yaitu yang menghambat produksi MMP. Selaput ketuban akan memberikan respon terhadap inflamasi sehingga menjadi tipis dan mudah pecah.

\section{KESIMPULAN DAN SARAN}

Berdasarkan analisis data yang dilakukan maka dapat ditarik kesimpulan adanya hubungan yang signifikan anta- 
ra anemia dan paritas dengan ketuban pecah dini pada ibu bersalin di RSUD Panembahan Senopati Bantul Tahun 2017, dengan hasil uji chi square didapatkan $p$-value sebesar $0.011<0.05$ pada anemia, dan hasil koefisiensi korelasi 2.765 dan pada paritas uji chi square didapatkan p-value sebesar $0.001<0.05$ dan hasil koefisiensi korelasi 0.286 sehingga dapat disimpulkan Ha diterima Ho ditolak yang berarti terdapat hubungan paritas dan anemia dengan ketuban pecah dini.

Bagi ibu hamil disarankan untuk secara teratur melakukan pemeriksaan ANC selama kehamilan dan meminum tablet tambah darah secara teratur untuk mencegah komplikasi kehamilan akibat dari anemia yang salah satunya adalah ketuban pecah dini.

\section{DAFTAR PUSTAKA}

[1] P. M. Duff, "Praterm Premature (Prelabor) Rufture Of Membrane," Uptodate, 2017. [Online]. Available: http:// www.uptodate.com/contens/preterm-premature-prelabor-rufture-of-membranes\#H450395235 .

[2] R. Mochtar, Sinopsis Obstetri: Obstetri Fisiologi, Obstetri Patologi, Ed. 3, Jilid I, 3rd ed. Jakarta: Buku Kedokteran EGC, 2010.

[3] BPS, "Survei Demografi dan Kesehatan Indonesia (SDKI) 2012," Badan Pusat Statistik, 2013.

[4] WHO, "Trends in Maternal Mortality," World Health Organization, 2015.

[5] Departemen Kesehatan Republik Indonesia, "Profil Dinas Kesehatan Provinsi D.I.Yogyakarta Tahun 2015," Jakarta, 2016.

[6] T. Nugroho, OBSYN Obstetri dan Ginekologi untuk Mahasiswa Kebidanan dan Keperawatan. Yogyakarta: Nuha Medika, 2012.

[7] M. Demiarti and S. Suharni, "FAKTOR-FAKTOR YANG MEMPENGARUHI KETUBAN PECAH DINI DI RSU PKU MUHAMMADIYAH BANTUL TAHUN 2016," Universitas' Aisyiyah Yogyakarta, 2017.

[8] E. K. Sari and H. Juaria, "Paritas dan Kelainan Letak Dengan Kejadian Ketuban Pecah Dini," Kebidanan, vol. 3, no. 1, 2018.

[9] I. Rahmawati and L. Mustaghfiroh, "Gambaran Paritas Ibu Bersalin Terhadap Kejadian KPD di RSUD Sunan Kalijaga Demak," J. Kesehat. dan Budaya, vol. 8, no. 01, 2016.

[10] T. Nugroho, Kasus Emergency Kebidanan untuk Kebidanan dan Keperawatan. Yogyakarta: Nuha Medika, 2010.

[11] I. A. C. Manuaba, Pengantar Kuliah Obstetri. Jakarta: Buku Kedokteran EGC, 2007.

[12] H. Wikjosastro, Ilmu Kebidanan. Jakarta: Yayasan Bina Pustaka Sarwono Prawirohardjo, 2010.

[13] F. G. Cunningham, et al, Obstetri Williams, 23rd ed. Jakarta: ECG, 2012. 